\title{
OCCURRENCE OF GREAT WHITE SHARK, CARCHARODON CARCHARIAS (ELASMOBRANCHII: LAMNIFORMES: LAMNIDAE), OFF CORSICA (NORTHERN MEDITERRANEAN): HISTORICAL AND CONTEMPORARY RECORDS
}

\author{
Vincent MALIET ${ }^{1}$, Christian REYNAUD ${ }^{2}$, and Christian CAPAPÉ ${ }^{3 *}$ \\ ${ }^{1}$ Corsica-Mediterranean Shark Research Group, Monte Nebbio-l'Orsala 20167 Appietto, Corsica, France \\ ${ }^{2}$ Laboratoire Interdisciplinaire de Recherche en Didactique, Éducation et Formation, \\ Université Montpellier II, Sciences et Techniques du Languedoc, Montpellier, France \\ ${ }^{3}$ Laboratoire d'Ichtyologie, case 104, Université Montpellier II, \\ Sciences et Techniques du Languedoc, Montpellier, France
}

\begin{abstract}
Maliet V., Reynaud C., Capapé C. 2013. Occurrence of great white shark, Carcharodon carcharias (Elasmobranchii: Lamniformes: Lamnidae), off Corsica (northern Mediterranean): historical and contemporary records. Acta Ichthyol. Piscat. 43 (4): 323-326.

Abstract. The capture of a juvenile, male, great white shark, Carcharodon carcharias (Linnaeus, 1758), off the Corsican coast (Mediterranean Sea) in 2012 is reported in this note along with two other new records (1976 and 2011). Additionally, 8 other historical and more recent records from the same area are presented and commented. These records are compared with those reported from more distant areas. Conclusions drawn based on the presently analysed material indicate that a sustainable and isolated C. carcharias population has probably established in the Mediterranean Sea, although more new records are needed to confirm this hypothesis.
\end{abstract}

Keywords: Chondrichthyes, Carcharodon carcharias, population, migration, successful establishment, Strait of Sicily

The great white shark, Carcharodon carcharias (Linnaeus, 1758), is a large shark, of global distribution, common in temperate and tropical seas and oceans. Its occurrence is well documented in the Mediterranean Sea, where the majority of records occurred in its central part, especially in the Strait of Sicily (Fergusson 1996, 2002, De Maddalena 2002, 2006, Cristo et al. 2006, Saïdi et al. 2005).

Since November 2011 the species has been studied by members of the Corsica-Mediterranean Shark Research Group (Corsica-MSRG), in order to assess the present status of its population around Corsica. The actions of the group have been supported by local fishermen actively helping the researchers in reporting relevant sightings and collection of the specimens. In the wake of this cooperation, on 30 August 2012, we were informed that a male specimen of Carcharodon carcharias was captured by trammel-nets, at a depths range of 190 and $200 \mathrm{~m}$, by $42^{\circ} 29^{\prime} 09.02^{\prime \prime} \mathrm{N}$ and $8^{\circ} 34^{\prime} 79.20^{\prime \prime} \mathrm{E}$ (Fig. 1, record 11), together with decapod species and some anglerfish, Lophius piscatorius Linnaeus, 1758. The specimen was $200 \mathrm{~cm}$ long (total length) and weighed approximately $200 \mathrm{~kg}$ (Fig. 2). Additionally, it exhibited developed and partially calcified claspers, suggesting that the specimen was probably juvenile. Unfortunately, the great white shark could not be preserved as a whole specimen and it was discarded at sea.

Additionally, of the four teeth that have been removed from the shark, two were preserved in the Ichthyological Collection of the Corsican Section of the Mediterranean Shark Research Group located in Appietto (Corsica); they received the following catalogue numbers: Corsica MSRG Car.-car. 01 and Corsica MSRG Car.-car. 02, respectively (Fig. 3).

Basic data collected while browsing old literature, published documents, interviews with fisherman, and personal observations showed that Carcharodon carcharias has historically occurred in the Corsican marine waters (Fig. 1, Table 1), but no voucher specimens have been preserved for confirmation. The first record of the great white shark off Corsica was reported in 1758, as determined from the 'Libro Rosso' of Morsiglia Convent, which is deposited in Archives départementales de Haute-Corse of Bastia (Corsiaca, France) under the catalogue number E85/13 (Anonymous 1758 unpublished). The second record concerned a large specimen having less than $5 \mathrm{~m}$ in total length, captured in 1829 and reported in 'Journal du Département de la Corse', deposited in Bibliothèque Municipale of

\footnotetext{
${ }^{*}$ Correspondence: Dr Christian Capapé, Laboratoire d'Ichtyologie, case 104, Université Montpellier II, Sciences et Techniques du Languedoc, 34095 Montpellier
} cedex 5, France, phone: +33467544162, e-mail: (ChC) capape@univ-montp2.fr; (VM) vml-msrg@sfr.fr. 
Ajaccio (Corsica, France), referenced under catalogue number FL-PER 1 (Anonymous 1829 unpublished).

Records 3 and 4 concerned shark attacks occurring in 1840, and reported in a document preserved in two copies, referred to as Fonds Ancien $n^{\circ} 42$ N 8 and Fonds Corse FL 12.146, respectively, preserved in the Bibliothèque Municipale of Ajaccio (De Lemps 1844). Records 6, 7, and 8 were reported by shark specialists (Miniconi 1994, De Maddalena and Heim 2012). Record 9 was from Dr Cecilia
Volpi and although unpublished in scientific literature, it was well documented and mentioned in two Italian daily papers such as 'La Repubblica-Firenze' (1 July 2001) (Volpi 2001a) and 'Corriere Fiorentino della Sera' (1 July 2001) (Volpi 2001b), and concomitantly deposited in the archives of the Italian regional television (RAI). All records from 6 through 9 provided a thorough description of white sharks caught in the marine Corsican waters. Record 5 (from 1976) established by us, as a new record, was based

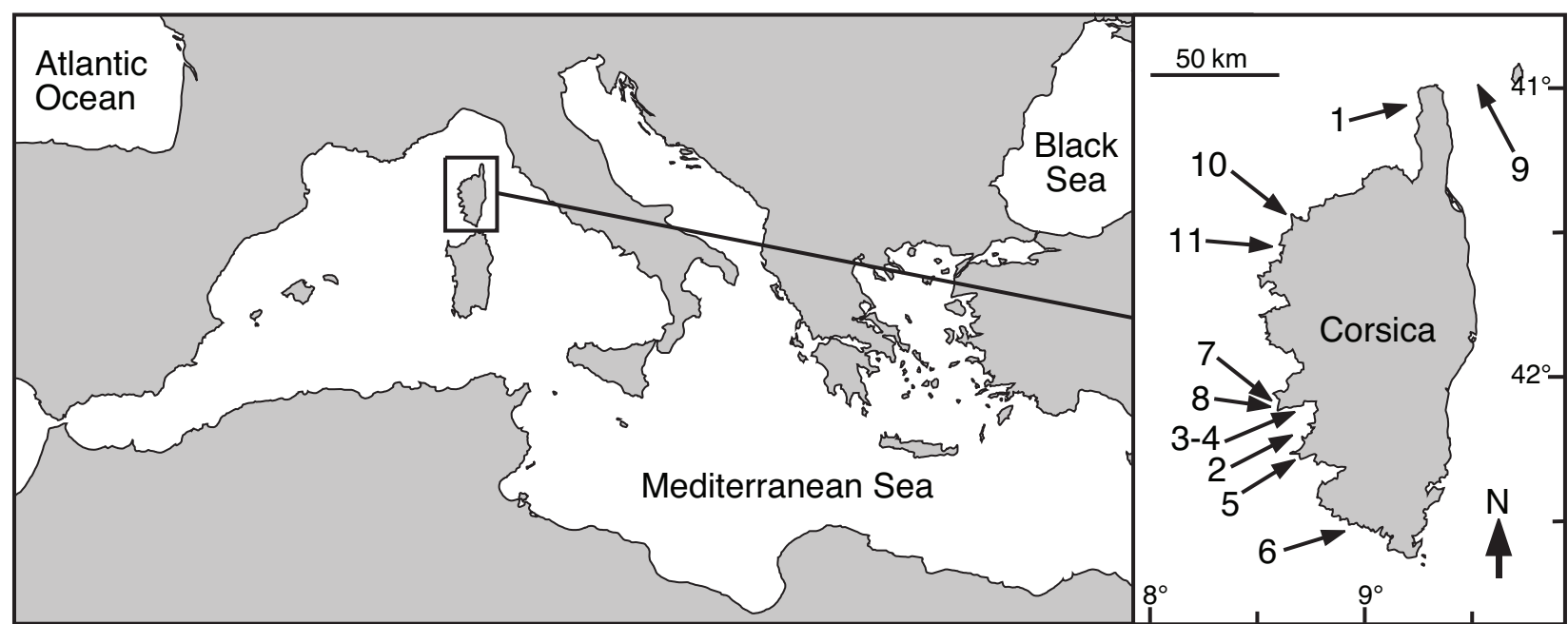

Fig. 1. Map of the Mediterranean Sea showing Corsica (inset) with all 11 captures sites of great white shark, Carcharodon carcharias (for complete information see Table 1)

Historical and contemporary records of great white shark, Carcharodon carcharias,

Table 1 from the Corsican coast

\begin{tabular}{|c|c|c|c|c|c|c|c|c|c|}
\hline Rec. & Sex & $\begin{array}{c}\mathrm{TL} \\
{[\mathrm{cm}]}\end{array}$ & $\begin{array}{l}\text { Weight } \\
{[\mathrm{kg}]}\end{array}$ & $\begin{array}{l}\text { Depth } \\
{[\mathrm{m}]}\end{array}$ & $\begin{array}{l}\text { Fishing gear/ } \\
\text { kind of record }\end{array}$ & Fishing site & $\begin{array}{l}\text { Part of } \\
\text { Corsica }\end{array}$ & Capture date & Reference \\
\hline 1 & - & - & ca. 653 & $>10$ & tonnara & Corsican Cape & $\mathrm{N}-\mathrm{W}$ & 7 Oct 1758 & $\begin{array}{l}\text { Anonymous } \\
\text { (1758 unpublished) }\end{array}$ \\
\hline 2 & - & $<500$ & - & $>10$ & tonnara & Gulf of Ajaccio & W & Jun 1829 & $\begin{array}{l}\text { Anonymous } \\
\text { (1829 unpublished) }\end{array}$ \\
\hline 3 & - & - & - & ca. 1 & attack? & Gulf of Ajaccio & W & early 1840 s & De Lemps (1844) \\
\hline 4 & - & - & - & ca. 1 & attack? & Gulf of Ajaccio & $\mathrm{W}$ & early 1840 s & De Lemps (1844) \\
\hline 5 & - & $<600$ & - & ca. 48 & trammel-net & Gulf of Ajaccio & $\mathrm{W}$ & 8 Sep 1976 & $\begin{array}{l}\text { This study } \\
\text { (new record) }\end{array}$ \\
\hline 6 & - & ca. 527 & ca. 1500 & $80-90$ & trammel-net & Les Moines & S-W & 14 Sep 1984 & Miniconi (1994) \\
\hline 7 & - & ca. 600 & - & ca. 1 & sighting & Capo di Feno & S-W & Feb 1995 & $\begin{array}{l}\text { De Maddalena } \\
\text { and Heim (2012) }\end{array}$ \\
\hline 8 & - & $350-450$ & - & ca. 1 & sighting & Gulf of Ajaccio & $\mathrm{W}$ & Apr 2010 & $\begin{array}{l}\text { De Maddalena } \\
\text { and Heim (2012) }\end{array}$ \\
\hline 9 & - & $<400$ & - & ca. 1 & sighting & Capraia-Corsica & $\mathrm{N}-\mathrm{E}$ & 21 Jun 2011 & $\begin{array}{l}\text { Volpi } \\
\text { (2001a, 2001b) }\end{array}$ \\
\hline 10 & - & ca. 400 & - & $20-25$ & sighting & Off Calvi & N-W & 10 Oct 2011 & $\begin{array}{l}\text { This study } \\
\text { (new record) }\end{array}$ \\
\hline 11 & $\widehat{0}$ & $180-200$ & ca. 100 & 190-200 & trammel net & Off Calinzana & N-W & 30 Aug 2012 & $\begin{array}{l}\text { This study } \\
\text { (new record) }\end{array}$ \\
\hline
\end{tabular}

Rec. $=$ record No. 
on an interview of a Corsican fishermen. Record 10 established by us, as a new record, was based on underwater observations carried out by two scuba divers, at the depth of 20-25 m, who spotted a shoal of thunnids chased by a white shark. All records observed in Corsican marine waters confirmed the occurrence of Carcharodon carcharias in the area, and consequently the species should be included in the list of local ichthyofauna. Unfortunately, these records did not constitute a sufficient statistical support to ensure that a local population of the great white shark is now established in the vicinity of Corsica.

A literature review based on comprehensive studies concerning white sharks and including local observations (Table 1) shows that 191 white shark records were reported, to date, in the western Mediterranean Basin and the Strait of Sicily (Fergusson 1996, 2002, De Maddalena, 2002, 2006, Bradai et al. 2004, Saïdi et al. 2005, De Maddalena and Revelart 2008, De Maddalena and Heim 2012). Francis (1996) noted that the length of a newly born white shark ranged from 1200 through $1500 \mathrm{~mm}$, and the female length at maturity was between 4.5 and $5 \mathrm{~m}$. The males of Carcharodon carcharias mature attaining a smaller length than females, as it is generally the rule in viviparous elasmobranch species (Mellinger 1989). Consequently, of the 191 specimens reported in the literature, 45 specimens having less than $4 \mathrm{~m}$ in total length were juveniles, and 146 other specimens had a larger size, exceeding $4 \mathrm{~m}$, were adults, the latter significantly outnumbered the former $\left(\chi^{2}=38.37, P<0.05\right)$.

Gubili et al. (2010) sequenced mitochondrial DNA in four specimens of Mediterranean great white sharks, collected from four different sites at different periods of the year, and noted that juvenile sequences were identical. Gubili et al (2010) showed little genetic differentiation from Indo-Pacific lineages, but strong separation from geographically closer Atlantic and western Indian Ocean haplotypes. These observations suggest that an isolated Mediterranean population of white sharks remains a justified hypothesis. The first Mediterranean record of Carcharodon carcharias was reported by Rondelet in 1540 (De Maddalena and Revelart 2008), and between 1540 and the opening of Suez Canal, which occurred in 1869 (Berneron-Couvenhes 2007), several other records were reported (Fergusson 1996, Soldo and Jardas 2000, Soldo and Dulčić 2005, De Maddalena and Heim 2012). C. carcharias has never been recorded from the Red Sea (Golani 1999); additionally, Quignard and Tomasini (2000) consider it as an indigenous Mediterranean species, and not as a Lessepsian migrant (Por 1978, Golani et al. 2002), consequently migrations from the Red Sea into the Mediterranean Sea should be ruled out.

Captures of juvenile and adult males and females, and pregnant specimens (Norman and Frazer 1937, Saïdi et al. 2005, Kabasakal and Özgür Gedikoğlu 2008) could suggest that a sustainable population has been established in the Mediterranean, but the collected records do not constitute sufficiently strong argument for a definitive conclusion about the status of $C$. carcharias in the Mediterranean Sea.

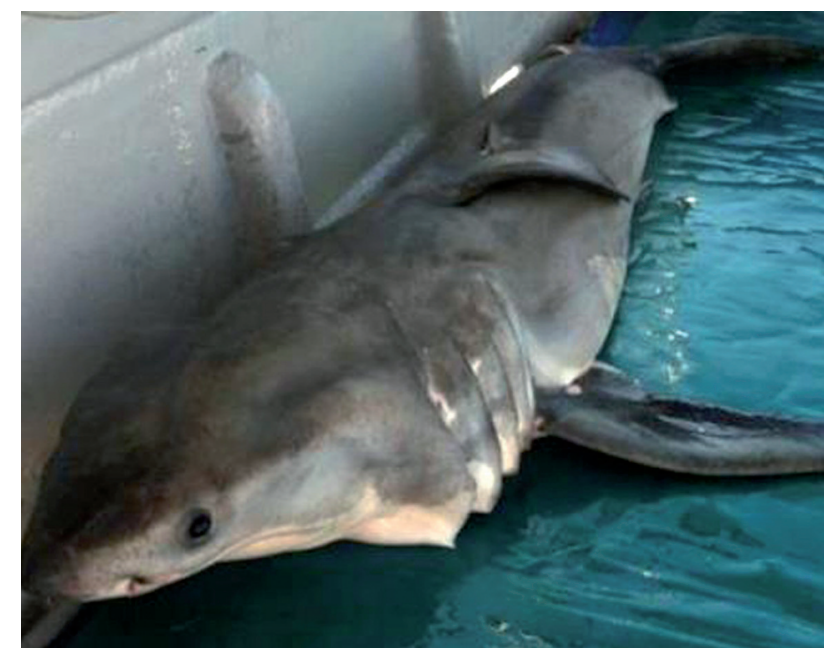

Fig. 2. A specimen great white shark, Carcharodon carcharias, captured off the Corsican coast on 30 August 2012, on the deck of the fishing boat (photo Toussaint Lunardi)

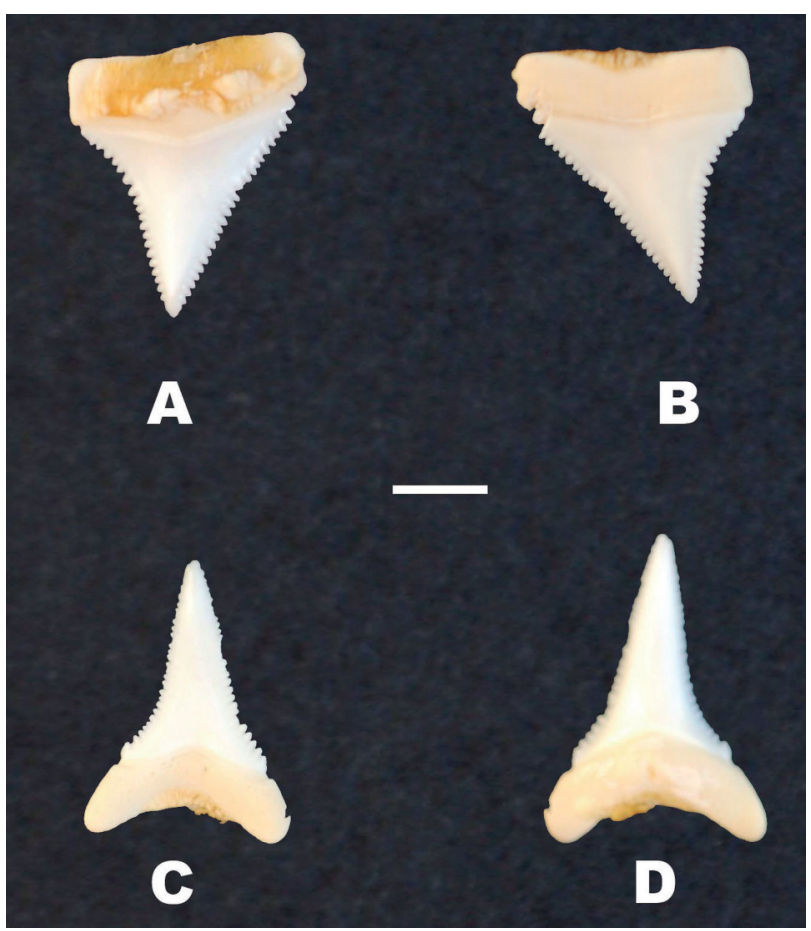

Fig. 3. Teeth of great white shark, Carcharodon carcharias, captured off the Corsican coast on 30 August 2012; A An upper-jaw tooth; middle row, inner view (ref. Corsica MSRG Car.-car. 01); B The same, outer view; C A lower-jaw tooth; middle row, inner view (ref. Corsica MSRG Car.-car. 02); D The same, outer view; Scale bar $=5 \mathrm{~mm}$

\section{ACKNOWLEDGEMENTS}

The authors wish to thank Mr Toussaint Lunardi and his son François, Corsican fishermen who kindly and rapidly informed us of the capture of the juvenile Carcharodon carcharias, gave us photographs and two teeth as gifts. 


\section{REFERENCES}

Berneron-Couvenhes M.F. 2007. Les Messageries maritimes, l'essor d'une grande compagnie de navigation française (1851-1894). Presses universitaires de Paris-Sorbonne, Paris, France.

Bradai M.N., Quignard J.-P., Bouain A., Jarboui O., Ouannes-Ghorbel A., Ben Abdallah L., Zaouali J., Ben Salem S. 2004. Ichtyofaune autochtone et exotique des côtes tunisiennes: Recensement et biogéographie. Cybium 28 (4): 315-328.

Cristo B., Storai T., Zuffa M., Zinzula L., Floris A. 2006. Presenza di Carcharodon carcharias (Chondrichthyes, Lamnidae) nelle acque sarde (Mediterraneo centrale). [Presence of Carcharodon carcharias (Chondrichthyes, Lamnidae) in Sardinian waters (central Mediterranean).] Biologia Marina Mediterranea 13 (1): 266-267. [In Italian.]

De Lemps J.H. 1844. Panorama de la Corse ou Histoire abrégée de l'île, et description des mœurs et usages de ses habitants. Édition A. Sirou, Paris.

De Maddalena A. 2002. Lo Squalo bianco nei mari d'Italia. [The white shark in the seas of Italy.] Edizione Ireco, Formello, Italy. [In Italian.]

De Maddalena A. 2006. A catalogue of great white sharks Carcharodon carcharias (Linnaeus, 1758) preserved in European museums. Časopis Národního muzea, Řada prírodovědná (Journal of the National Museum Natural History Series) 175 (3-4): 109-125.

De Maddalena A., Heim W. 2012. Mediterranean great white shark. A comprehensive study including all recorded sightings. McFarland and Company Publishers, Jefferson NC, USA.

De Maddalena A., Revelart A.-L. 2008. Le grand requin blanc sur les côtes françaises. Turtle Prod éditions, Plongée Magazine, Hyères, France.

Fergusson I.K. 1996. Distribution and autoecology of the white shark in the eastern North Atlantic and the Mediterranean Sea. Pp. 321-345. In: Klimley A.P., Ainley D.G. (eds.) Great White Sharks: The Biology of Carcharodon carcharias. Academic Press, San Diego, CA, USA.

Fergusson I.K. 2002. Occurrence and biology of the great white shark, Carcharodon carcharias, in the Central Mediterranean. Pp. 7-23. In: Vacchi M., La Mesa G., Serena F., Séret B. (eds.) Proceedings of the 4th European Elasmobranch Association Meeting, 27-30 September 2000, Livorno, Italy.

Francis M.P. 1996. Observations on a pregnant white shark with a review of reproductive biology. Pp. 157-172. In: Klimley A.P., Ainley D.G. (eds.) Great White Sharks: The Biology of Carcharodon carcharias. Academic Press, San Diego, CA, USA.

Golani D. 1999. Madrich ha'Dagim shel Israel. [Guide to the fishes of Israel.] Keter Publishing House, Jerusalem, Israel. [In Hebrew.]
Golani D., Orsi-Relini L., Massuti E., Quignard J.-P. 2002. CIESM atlas of exotic species in the Mediterranean. Vol. 1. Fishes. Commission Internationale pour l'Exploration Scientifique de la Méditerranée (CIESM), Monaco.

Gubili C., Bilgin R., Kalkan E., Karhan S.Ü., Jones C.S., Sims D.W., Kabasakal H., Martin A.P., Noble L.R. 2010. Antipodean white sharks on a Mediterranean walkabout? Historical dispersal leads to genetic discontinuity and an endangered anomalous population. Proceedings of the Royal Society of London, series B: Biological Sciences 278 (1712): 1679-1686. DOI: 10.1098/rspb.2010.1856

Kabasakal H., Özgür Gedikoğlu S. 2008 Two new-born great white sharks, Carcharodon carcharias (Linnaeus, 1758) (Lamniformes; Lamnidae) from Turkish waters of the north Aegean Sea. Acta Adriatica 49 (2): 125-135.

Mellinger J. 1989. Reproduction et développement des Chondrichthyens. Océanis 15: 283-303.

Miniconi R. 1994. Les poissons et la pêche en Méditerranée, la Corse. Vol. 1. Edition Piazzola et la Marge, Ajaccio, Corse, France.

Norman J.R., Fraser F.C. 1937. Giant fishes, whales and dolphins. Putnam, London, UK.

Por F.D. 1978. Lessepsian migration. Ecological studies. Vol. 23. Springer-Verlag, Berlin-Heidelberg-New York.

Quignard J.-P., Tomasini J.A. 2000. Mediterranean fish biodiversity. Biologia Marina Mediterranea 7 (3): 1-66.

Saïdi B., Bradaï M.N., Bouaïn A., Guélorget O., Capapé C. 2005. Capture of a pregnant female white shark, Carcharodon carcharias (Lamnidae) in the Gulf of Gabès (southern Tunisia, central Mediterranean) with comments on oophagy in sharks. Cybium 29 (3): 303-307.

Soldo A., Dulčić J. 2005. New record of a great white shark, Carcharodon carcharias (Lamnidae) from the eastern Adriatic Sea. Cybium 29 (1): 89-90.

Soldo A., Jardas I. 2000. Large sharks in the eastern Adriatic. Pp. 141-155. In: Vacchi M., La Mesa G., Serena F., Séret B. (eds.) Proceedings of the 4th European Elasmobranch Association Meeting, 27-30 September 2000, Livorno, Italy.

Volpi C. 2001a. Avvistato uno squalo nelle acque di Capraia. [Spotted a great white shark in waters of Capraia.] La Repubblica Firenze.it 01 luglio 2011 (Cronaca il mare).

Volpi C. 2001b. Avvistato squalo bianco a sei miglia da Capraia. [Spotted a white shark six miles off of Capraia.] La Repubblica Firenze.it 02 luglio 2011 (Archivio).

Received: 4 June 2013

Accepted: 14 November 2013

Published electronically: 31 December 2013 